\title{
Living the good death: palliative care for the wise
}

\section{Keywords: palliative care, death bed, brushes, death, forgiveness Opinion}

On the one hand, most people would agree that there is a way to live well. They would d not likely on what it means to live well; they would agree that is such a thing as a better life. On the other hand, most people with some life experience under their belts would agree that there is a better way to die. Although I haven't experienced palliative care myself except vicariously for family, and from my own near brushes with death, I conclude that there are three pillars that encompass the way to die well. They involve family; faith, and forgiven mess. For those who don't have much too family ties, will insert friends.

We take family (or friends) first. When you are on your death bed, very little outside of relationship matter. You can't take it with you reminds us that our stay here is brief. We exit this world the same way we entered it-with nothing. In fact, we enter it with our mother (and father.). Quickly we learn the words momma, and dadda, and brother and sister. Frequently we are raised by grandparents, aunts and uncles for better worse. If we are missing these bedrock ties, we suffer in life. But most of us (frequently fewer nowadays with the implosion of the nuclear family), find that these people who were our bedrocks in life are on our minds when we face the potential last breath. It seems not to matter the experiences we've had with our family-sweet or bitter -but nonetheless we reach out cognitively, if not literally to our family. I suspect it is the same for those who had fronds in place of family We tend to regret what we did or didn't do to engage our family and friends in a better effort. So family is paramount for the dying person. Love lost through life may be made up on the death bed.

It brings us to forgiveness. Most of us have enemies whether we want to have them or not. Its part of the human experience to have enemies, or those who get into our path of progress. Some of these enemies are more destructive than others. Some are downright evil in their plots and plans. I suppose that such enemies have a terrible death bed. But their death bed is not the one we are presently concerned with. For our death bed to be bearable, we must try our hardest to forgive our enemies. Jesus said it better, "Love your enemies." No other philosopher said to love to this degree. It's difficult to forgive those people who come into our lives under different circumstances. They may be a boss, co-worker, fellow student; a spouse, a parent etc. Holding a grudge on our death bed injures ourselves more than anyone. The classic parable of "The prodigal Son, (better titled the prodigal father.) shows what love and mercy and kindness brings a reunited family. Jesus spoke of the Woman caught in adultery. "Let he who is without sin cast the first stone." The onus is upon us to forgive those who have injured us. One priest said, he was the one who did more damage to himself than anyone. To be peace with ourselves on our death bed, we must forgive. That includes especially forgiving ourselves.

\author{
Volume 2 Issue 4 - 2018
}

\author{
Paul TE Cusack \\ BScE, Canada
}

Correspondence: Paul TE Cusack, Dule, BScE, 23 park Ave, Saint John, NB E2J IR2, Canada, Fax (506) 652-6350, Email St-michael@hotmail.com

Received: July 03, 2018 | Published: July 27, 2018

Finally, we consider faith. I'm a Catholic and believe it is the only true faith of=established by the God-man Jesus. Nevertheless, we must have something to look forward to doing to avoid self destruction- in life and in death. Not believing in anything beyond the grave ahs got to be one of the worst stances to have in life and in death. I've shown through my papers on Astro-theology and exploring the Truths of the Bible, that some incorrectly consider myth, that God is real; there is an afterlife; we have a should. Everyone's should have a destiny. To die well, we must have faith that our journey continues. Jesus said, "Many are lost for lack of knowledge." Or "How I wish they were hot or cold; because they are luke warm I'll vomit them from my mouth."

So, there we have family (friends); forgiveness; and faith. Life is precious and tenuous. One thing certain, we all face dying. Its the universal equalizer. How we treat one another, ourselves and God is the purpose to life. It's too bad some of us must wait until our death bed before we figure that one out. If we want to die a peaceful life, we must live a peaceful life. We can only be at peace in treating God, our neighbour, and ourselves according to God's Commandants.

My mother is gradually dying with Dementia. She feels it important to tell me that

i. She had lived a life with faith in God;

ii. I've enjoyed every minute with you;

iii. You never gave us trouble.

Faith, family, forgiveness. This is palliative care for the wise.

\section{Acknowledgements}

None.

\section{Conflict of interest}

The author declares no conflict of interest. 